\title{
Greece as a Spiritual Home: Gerhart Hauptmann's Travel Diary Griechischer Frühling
}

\begin{abstract}
By Jennifer E. Michaels ${ }^{*}$
From the end of March to the middle of May 1907 Hauptmann visited among many other places in Greece Corfu, Athens, Delphi and Sparta. Hauptmann, who was well versed in Greek mythology, did not focus on Greece's classical art that had previously so impressed such Germans as Winckelmann and Goethe. Instead, Greece was for him sensuous and mystical. Like Nietzsche, he was interested in the preclassical archaic period of Greece rather than in the harmony of the classical period. He stresses the Dionysian and rejects notions of classical antiquity as the embodiment of noble simplicity and quiet grandeur. Hauptmann's is not a scholarly approach to Greece. He was overwhelmed by Greece's beauty that appealed to his senses: the landscape with its myriad flowers and brilliant colors; the fragrance of oranges, pomegranates, eucalyptus and thyme; the sounds of flowing water and the bells on the sheep; the songs of the birds and the buzzing of bees. Wherever he went, he felt the closeness of the gods and thought of Odysseus and Homer. Hauptmann was drawn to what he saw in the Greek tradition as the life affirming as well as the destructive Dionysian forces. He viewed Greek tragedy as the breaking through of the chthonic powers of the abyss into the light and also as a divine offering to the gods. For him Greece felt like a spiritual home. I focus here on Hauptmann's reception of Greece in his travel diary Griechischer Frühling (1908; Greek Spring).
\end{abstract}

From the end of March to the middle of May 1907 Gerhart Hauptmann with family and friends visited among other places in Greece Corfu, Corinth, Athens, Delphi and Sparta. They continued on to Turkey from 17 May until 24 May where they spent time in Istanbul. ${ }^{1}$ In his travel diary Griechischer Frühling (1908; Greek Spring) ${ }^{2}$ Hauptmann leaves a vivid, impressionistic and highly personal account of this journey: 'He came to see with his own eyes and not another's, and he has given us Hellas as he felt it' (Oldfather 18). For him Greece felt like a spiritual home. His is not a scholarly, but rather a sensuous

\footnotetext{
*Professor, Grinnell College, USA.

${ }^{1}$ For a discussion of Hauptmann's reactions to Turkey see Mehmet Uysal, 'Einst war Gerhart Hauptmann in Istanbul: Ein Beitrag zur Untersuchung der deutschen Reiseberichte über die Türkei,' Journal of Social Sciences 20 (2009): 253-264.

${ }^{2}$ The title 'Greek Spring' refers to the actual time of Hauptmann's visit, but also suggests the spring of Greek art, the pre-classical period that fascinated him.
} 
and mystical response to Greece (Garten 39). He was overwhelmed by Greece's beauty and wherever he went he felt the closeness of the ancient Greek gods and heroes. Like Nietzsche, he was interested in the pre-classical period and he rejects notions of classical antiquity as the embodiment of noble simplicity and quiet grandeur 'in favor of an archetypal, cultic, and Dionysian view' (Maurer 101). This leads him to interpret Greek tragedy both as the breaking through of the chthonic powers of darkness into the light and as a divine offering to the gods. I discuss here Hauptmann's reception of Greece in Griechischer Frühling, a work that has been somewhat neglected in Hauptmann scholarship, but that was significant for his later works.

During his life Hauptmann (1862-1946), who won the Nobel Prize for Literature in 1912, was celebrated as the greatest German writer. He was a prolific author who was successful in many genres. He is known mainly for his dramas, both tragedies and comedies, but he also wrote prose and verse novels and short stories. Not only did he write in diverse genres, but in his works he also used diverse styles and addressed a variety of themes. Hauptmann, who was deeply rooted in his native Silesia, gained fame (and notoriety) as a Naturalist dramatist, for example with his controversial play Die Weber (1892; The Weavers) in which he depicts the plight of the desperate Silesian weavers and their abortive attempt to change their brutal working conditions. Many of his early plays are set in northern Germany and address problems of growing industrialization and issues of modernity, but he also evokes the scenery of the north, its forests, mountains and sea. Hauptmann visited Italy, which he loved, several times. He worked as a sculptor in Rome in 1883-84, but was not successful: his enormous sculpture of a Germanic warrior collapsed (Maurer 10). He often refers to Italy in his works. For example, in his play Und Pippa tanzt! (1906; And Pippa Dances) he depicts Venice as a magical city, a contrast to the mid-winter Silesian north of the play's setting. He moved away from his early Naturalism and was drawn to New Romanticism and symbolism: a symbolist dream play Hanneles Himmelfahrt (The Assumption of Hannele) appeared in 1893. He became fascinated with fairy-tales, as for example in his play Die versunkene Glocke (1896; The Sunken Bell), and with legends, myths and medieval romance. Hauptmann despised the Nazi regime, but his rootedness in Silesia, and perhaps also his age at the time, led him to decide not to go into exile as many other Germans, including leading writers, had done. His decision to stay in Germany was a propaganda coup for the Nazis who, as with the 1936 Olympics, used his fame to help validate their regime. His refusal to leave Germany led to a decline in his reputation during the immediate postwar years.

In Griechischer Frühling Hauptmann writes that since he was eighteen years old he had longed to visit Greece, but the marvels of Italy had distracted him. He had planned trips to Greece, but was not able to carry them out, and he thought he would never see this country. On the ship to Greece, he can still scarcely believe he is actually going there. ${ }^{1}$ His visit to Greece was a fruitful

${ }^{1}$ Gerhart Hauptmann, Griechischer Frühling (Berlin: Fischer, 1908), 12-13. Future references are to this edition and will be given in the text. Translations are my own. 
one for his later works. After this visit, Greek mythology and literature increasingly pervade his work. In 1914, for example, he wrote the play Der Bogen des Odysseus (The Bow of Odysseus), inspired by Homer's depiction of Odysseus's return home after many years of wandering and his meeting with the faithful herdsman Eumaeus. At the end of his life, he again turned to Greek mythology in Die Atriden-Tetralogie (The Atrides Tetralogy), which he wrote from 1940-44, reworking dramas by Euripides, Aeschylus and Sophocles. This tetralogy, written in iambic pentameters, consists of Iphigenie in Aulis (1944), Agamemnons Tod (The Death of Agamemnon), Elektra and Iphigenie in Delphi (1941). Agamemnons Tod and Elektra were published posthumously in 1948. As in Griechischer Frühling, in which he mentions Agamemnon, Clytemnestra and Orestes, Hauptmann focuses on Greece's pre-classical age. Heightened by the horrors of the Nazi period, these plays express a sense of 'inexorable fate' and tragedy (Garten 49). ${ }^{1}$

Hauptmann scholars have recognized his visit to Greece as an important turning point for his later work, but have been less interested in Griechischer Frühling, which was widely read when it was first published, as a travel account, perhaps because travel literature 'was usually dismissed by literary critics and cultural commentators as a minor, somewhat middle-brow form' (Thompson 2), as an 'insignificant and sub-literary' genre (Thompson 13). In the last decades, however, academic interest in travel literature has increased (Thompson 2), a consequence of post-colonialism and globalization and the subsequent interest in how other cultures have been depicted and appropriated. Edward Said's Orientalism (1978) was 'enormously influential in awakening scholarly interest in travel writing, a genre that had previously been little studied' (Thompson 61). Recent reissues of Hauptmann's travel diary suggest renewed interest in his perceptions of Greece. ${ }^{2}$ By using the diary form Hauptmann gives immediacy to his impressions. His actual diary was, of course, filtered and edited for publication, but it nevertheless provides the reader with vivid impressions of the Greek landscape and insights into Hauptmann's idiosyncratic responses to ancient Greek culture. Throughout the diary he employs fantasy and imagination. The diary, written sometimes in the first-person singular when he makes a journey alone, sometimes in the first person plural when he is with friends and family, emphasizes the authenticity of his responses. Hauptmann's language, full of such expressions as 'intoxicated with beautiful expectations' (20-21) and 'inexpressible joy of existence' (40), reinforces his subjective and ecstatic response to Greece.

Since the eighteenth century, many German writers have been attracted to the south, to Italy and Greece, for the climate, the beauty, and the antiquities, and Hauptmann belongs to this tradition. In particular, his travel diary engages

\footnotetext{
${ }^{1}$ For a recent study of Hauptmann's tetralogy, see Anica Petrovic-Wriedt, Zwischen Tradition und Zeitbezug - Gerhart Hauptmanns Atriden-Tetralogie (Munich: Grin Verlag, 2010). See also Daria Santini, Gerhart Hauptmann zwischen Modernitat und Tradition: Neue Perspektiven zur Atriden-Tetralogie (Berlin: Erich Schmidt, 1998). As the publication dates show, Hauptmann did not write the plays in the chronological order of the myth.

${ }^{2}$ See Christopher Meid, Griechenland-Imaginationen: Reiseberichte im 20. Jahrhundert von Gerhart Hauptmann bis Wolfgang Koeppen (Berlin: De Gruyter, 2012).
} 
with discourses of the time about Hellenism. In 1764 Johann Joachim Winckelmann (1717-68) published his pioneering Geschichte der Kunst des Alterthums (The History of Ancient Art), in which he stressed the superiority of Greek art. His views influenced scholars and writers throughout Europe in the late eighteenth and nineteenth centuries and fostered an engagement with Hellenism that became so pervasive that it has been called 'the tyranny of Greece over Germany. ${ }^{1}$

Winckelmann, who never visited Greece, considered Greek art of fifth century B.C. Athens sublime. He admired what he saw as the beauty and harmony of Greek sculpture, his particular focus. For him the statues represented simplicity, repose, serenity, proportion, and truth to nature. He believed that all beauty is heightened by unity and simplicity (Winckelmann $1850,44)$. In his view such noble art emerged because of the climate, but especially because what he perceived as Athens' democratic government fostered artistic expression. He saw in the Greek character humanity and a joyous disposition. Unlike the Romans, who enjoyed gladiatorial games, the Greeks abhorred such cruelty (Winckelmann 1850, 9). His aesthetics influenced among others Johann Wolfgang von Goethe, and Friedrich Schiller, the leading writers of the Weimar Classicism of early nineteenth century Germany. Goethe's drama Iphigenie auf Tauris ${ }^{2}$ was, in fact, considered the beginning of Weimar classicism. As more became known about pre-classical Greece from archeological excavations in the nineteenth century, the canonized versions of ancient Greece, espoused by Winckelmann, Goethe and Schiller, were challenged, most famously by the philosopher Friedrich Nietzsche in Die Geburt der Tragödie (1872; The Birth of Tragedy) in which he stresses the role of the Dionysian in the origins of Greek tragedy. Hauptmann's travel diary shows his familiarity with such discourses about Hellenism to which he adds his own reflections.

Although the focus of his travel diary is the landscape and ancient Greek culture, the socially critical Hauptmann was not blind to the poverty of some of the regions he visited. In Corfu, for example, he notices children begging and a mother picking lice out of her child's hair. He reports having to avoid brutish beggars, one of whom he describes as a lice-infested, half naked ghost with a racking cough (33). He vividly depicts a garbage heap close to his hotel where desperately poor people compete with stray dogs for left over food. In their poverty they wander from garbage heap to garbage heap, and he is shocked by what he calls an incomprehensible fate of misery (54-55). When leaving Piraeus for Delphi by sea, he notices a ship in the harbor full of Greeks forced to emigrate to America because the land of the Greek soul can no longer nourish them (130). Mostly, however, he is annoyed by the noise and dirt of the modern cities. In Patras, for example, he expresses a longing to return to the 'un-modern' (81). In Athens, he notes that one has to overcome the noise

\footnotetext{
${ }^{1}$ See Eliza M. Butler, The Tyranny of Greece over Germany (London: Cambridge University Press, 1935).

${ }^{2}$ Goethe wrote Iphigenie auf Tauris in 1779 in prose form. He wrote a version in 1786 in verse, in iambic pentameters.
} 
before the spirit can devote itself undisturbed to the yearned for past (88). Although Hauptmann sympathizes with poverty, his interest is in Greece's ancient past, not in its present social and political reality.

Hauptmann felt himself as German and Silesian, but also as a diasporic Greek (Guthke 15). Throughout his travel diary he draws connections between the ancient Greeks and the ancient Germans. Like the Homeric Greek the ancient German was a warrior, a daring seafarer, deeply pious, but also prone to overindulgence in food and drink. Both ancient Greeks and ancient Germans valued games and athletic competitions. Referring to Plutarch Hauptmann claims that the Greeks came from the north (45-46). Sometimes Hauptmann notices Greeks who remind him of Germans, such as peasants who appear to be of noble German type and a young girl with blond hair (146-47), comments that suggest northern Eurocentric views. He also draws parallels between northern and southern landscapes and climates. Traveling by train along the Gulf of Corinth he is reminded of Lake Garda in Switzerland. Everything here, he observes, is of a refreshing, almost Nordic simplicity (82), and some places remind him of Norway or of Alpine valleys. He sometimes feels a fresh northern wind, and in Athens the weather is like a German spring (97). Through such reflections he tries to bridge the binarism of north and south by stressing connections and similarities.

Throughout his diary Hauptmann focuses on the, for him, overwhelming beauty of Greece. He was fascinated with the landscape and explored the countryside, sometimes by train, but also on mules, horses or on foot. Often employing Romantic tropes of the sublime, he expresses his awe and wonder at the landscape. In Corfu he spends time in an overgrown garden belonging to the king (he calls it the garden of Circe), a wildness that appealed to Romantic notions of landscape. Among the sources of wonder to him are the myriad flowers, which he calls holy beings (24). In his view, paradise will be a land full of unknown exquisite flowers. Corfu's beautiful anemones, in fact, give him an inkling of another world (40). Lying in a meadow amid flowers he is overcome by an intense joy (123). He mentions the scent of oranges, pomegranates, and eucalyptus and writes that all of Greece is fragrant with thyme, myrrh and marjoram (225). He hears the sounds of flowing water, the bells on the sheep and goats, the buzzing of bees and the songs of the birds. The twittering of swallows seems to him like a strange music (105). He is impressed by the brilliant colors, the dazzling light and the snowcapped mountains. His response to the landscape is sensuous. Hauptmann considers the world of the senses as part of the soul (166) and believes that religious feeling has its deepest roots in nature (147). In his view, the richness of the ancient Greek soul derived from the richness of the Greek soil (234).

Through the beauty of the landscape Hauptmann senses the Greek past. Wherever he goes, he feels the living presence of the ancient Greek gods. In a small ruined temple in Corfu he imagines that he has always been the servant of the immortal Greek gods. At the spring near the temple he reflects that he is here to worship the gods, to love them, and to let them rule over him (42). $\mathrm{He}$ envisions nymphs and nyads and experiences an intoxication through which 
nature and myth become one (51). The flocks of goats and sheep with their herdsmen suggest to him the presence of Pan and Dionysus. When he visits Olympia he thinks of Zeus struggling with Kronos for the rule of the world, and near Eleusis the fertile landscape makes him think of Dionysus and the earth goddess Demeter. Hauptmann views Demeter as a goddess whose suffering brings her closer to human beings. He writes that although Zeus allowed her daughter Persephone to return from Tartarus for part of each year, Demeter's existence, like that of all people, includes joy and separation, enjoyment and loss (118-19). Thinking about Dionysus Hauptmann regrets that he is not musically talented. If he were blessed with this Dionysian art he could express himself without having to struggle for words (151). In Delphi among the ruins he feels the invisible and continuing presence of demons and gods and especially Pan (165).

Thoughts of the ancient gods lead Hauptmann to reflect on ancient Greek religion and contrast it to Christianity. In his view, the Greek gods and demigods were closely bound to the Greek soil and made the whole area holy. Because the peasant's soul was strong and naïve, his gods were similarly strong and naïve (85): the ancient Greeks, he muses, imagined and created gods like themselves. He praises the Greeks for still being naïve, for retaining a child-like view of the world even into old age (133). They have preserved the power of fantasy that has been lost and profaned in the modern, scientific and skeptical world where myths no longer exist (139). For him, Greek religion contains joy and life. He argues that polytheism and monotheism do not exclude each other. In his opinion, monotheism makes it hard for people to conceive of God, hence their need for earthly gods more like themselves with whom they can identify, and such gods, he believes, represent different manifestations of the one God (141). To underscore the differences between his perceptions of ancient Greek religion and Christianity he contrasts temples and churches. In his view, Greek temples were the dwellings of the gods, and their rituals celebrated the joy of life (97). In contrast, churches have lost this love of life and have become mausoleums, dedicated to the underworld, and a major reason why people go there is because they fear death (95-96). Hauptmann does not reject Christianity, but rather criticizes how it has become distorted since the time of Jesus. By the bay of Eleusis, which he likens to the Sea of Galilee, he reflects about Jesus encouraging fishermen to become fishers of men and is reminded of the flight to Egypt (114-15). Like Demeter, Hauptmann observes, Jesus suffered an earthly-human fate, and this suffering brings him closer to us (116).

Hauptmann sees in the landscape not only the abode of the gods, but also of mythical Greek heroes. When Winckelmann imagined the stadium at Olympia, he seemed to see 'countless statues of young, manly heroes, and twohorse and four-horse chariots of bronze, with the figures of the victors erect thereon, and other wonders of art' (Winckelmann 1850, 27). In this stadium Hauptmann, however, imagines hearing living runners and wrestlers in the athletic competitions. Near Eleusis he conjures up a vision of a troop of young men from Athens around the time of Perikles, a vision so vivid that he thinks 
he can really hear the young men laugh and breathe. Unlike Winckelmann who imagines life turned into art, Hauptmann visualizes the living ancient Greeks. In Corinth he thinks of the tragedy of Periander, Melissa and Lykophron and later of Agamemnon, Clytemnestra and Orestes. In Sparta he reflects on Lycurgus and the values of courage, discipline, austerity and military fitness he imposed.

His guide through his journey is often Homer, not the Homer of The Iliad but of The Odyssey, which Hauptmann had recently reread. On the ship to Greece he thinks of Odysseus, whom like Homer he calls a cunning liar, and reflects that in The Odyssey Homer portrays Poseidon as treacherous. Hauptmann notes wryly that the seasickness, suffered by several on the ship, is Poseidon's spiteful act of revenge (9). In his diary he quotes passages from Homer and in Corfu he sees the place where, according to legend, Odysseus landed and met Nausicaa who befriended him. In the wild garden he begins to write a poem, in which Odysseus's son Telemachus will be the protagonist, to submerge himself in the Homeric world. When he sees beggars he thinks of Odysseus and also of Homer who went from place to place as a blind beggar (55). The numerous shepherds and goatherds he encounters remind him of Eumaeus whom he calls the divine herdsman, a figure that has long been alive to him (36), and who will feature prominently in the later Bogen des Odysseus. He reflects on other characters from The Odyssey, such as Circe and Calypso. Hauptmann believes that Homer's great act of creation was to give the Greeks a rich heritage of characters. Homer's verses, he stresses, are songs of praise, not evocations of the dead (220). Like Nietzsche, Hauptmann views Homer as an integral part of the Greek spirit: 'the dreaming Greek as a Homer and Homer as a dreaming Greek' (Nietzsche 25), and as the 'prototype of the Apollonian naïve artist' (Nietzsche 36).

Hauptmann had little interest in seeing sculptures of classical Greek antiquity that had inspired Winckelmann and Goethe. Only twice does he mention visiting a museum, the small museums of Olympia and Sparta. In the museum in Olympia his response to the famous statue of Hermes by Praxiteles is not to focus on the sculpture as art, but rather to see in it Hermes, the god (79). When he visits the Parthenon, he is at first disappointed by what he senses as its power and seriousness (94). In discussing sculpture, Winckelmann argued that white is 'the color which reflects the greatest number of rays of light, and consequently is the most easily perceived.' In his view, the whiter a work, the more beautiful it is (Winckelmann 1850, 40). In contrast, Hauptmann imagines the former brilliant colors of the Acropolis. He acknowledges that some would consider such brightly colored painting barbaric and adds, without specifying names, that he has never been able to stand what be calls the weak 'Griechisieren,' which he defines as the bloodless love for a bloodless Hellenism (94). Hauptmann's response to the Parthenon changes when he visits it at night. In the different light it no longer appears massive or threatening, but as a structure of air; it is no longer an edifice of dead marble, but seems to live (128). The ancient Greece Hauptmann visualizes is a living one of color and joy. Like Nietzsche, whose shadow is evident in the travel 
diary, Hauptmann deplores 'ineffectual fine talk about "Greek harmony," "Greek beauty," and "Greek serenity"” (Nietzsche 122).

Throughout the diary Hauptmann refers to Greek dramatists. For example, when he hears frogs croaking in Olympia or birds on the Acropolis he thinks of Aristophanes. As a dramatist, he was fascinated with the origins of drama. On his visits to the theater of Dionysus at the Acropolis and the theater at Delphi he reflects on Greek drama. Hauptmann disagrees with German classicists' notions of the purity of form of Greek tragedy and more closely follows Nietzsche's views. In Die Geburt der Tragödie Nietzsche challenges the 'alleged "serenity" of the Greeks and Greek art (Nietzsche 3), and argues instead that the Dionysian spirit gave rise to tragedy. Nietzsche believes that art evolves from the Apollonian-Dionysian duality, from the self-restraint and selfknowledge of the Apollonian and the Dionysian rapture and excess. In his view Greek tragedy is 'the expression of two interacting artistic impulses, the Apollonian and the Dionysiac,' both of which are essential (Nietzsche 76). Despite his stress on balance Nietzsche was particularly fascinated with the Dionysian.

Among the ruins of the theater of Dionysus in Athens Hauptmann reflects on the terrible world of tragedy, but also senses in the surroundings something light and spiritual that is in harmony with the goddess Athena (90). He considers joyfulness the highest form of human life, the joyfulness of a child that in an old man or a people either disappears or else gives rise to comedy, and he reminds his readers that tragedy and comedy were folk forms and used similar material. Criticizing the theater of his time he stresses that tragedy and comedy have nothing in common with weak, over-refined nerves (91). In the Dionysian festivities that used to be held on the south side of the Acropolis, he sees an overflowing gaiety and energy and out of this, not out of weakness and flight from life, arise tragedy and comedy (92). Above the theater towers the throne of the gods on the Acropolis where Hauptmann can still sense their presence. Hauptmann speculates that all tragic dramatists up to Euripides, even if they had moved away from the naïve beliefs of the people, must have been instilled with awe of the gods in this theater at the foot of the Acropolis (100). Having gods as their audience shaped the form of their dramas in which gods and people intermingle (103). Hauptmann calls such dramas the divine reflection of the noble soul of the people. He believes that the poet's art should be the heightened expression of this soul (103) and he also stresses the Dionysian life-affirming joyousness.

In Delphi, however, Hauptmann senses the darker side of the Dionysian. For him, Delphi was a source of chthonic power (162). In the wild majesty of the natural surroundings he thinks about Apollo and Dionysus, but not, he emphasizes, about their classical statues, but instead about ancient wooden idols. As in Athens the plays were performed for the gods, who remain for him invisibly present, but in Delphi, Hauptmann believes, they were a cruel, bloodthirsty audience. The chthonic powers, he states, have not been conquered. In his view the root of tragedy was human sacrifice (169), and he defines tragedy as enmity, persecution, hatred and love, as fear, danger and 
suffering, as murder, thirst for blood, and incest (171-72). For him the temple area is steeped in the blood of the goats that replaced human sacrifice. He pictures the priests who performed the sacrifices covered in blood, and the theater filled with a bloody mist, the death rattle of the sacrificed animals and the smoke of the burnt offerings (173-74). Encountering black, demoniclooking goats he imagines himself in the realm of Dionysus and Pan as he approaches Parnassus (200), but the dazzling light makes him also think of Apollo (202). Hauptmann sees tragedy as a break through of the chthonic powers into the light (222). He argues that the fearful chthonic cloud rose into the Olympian ether and competed with the Homeric clouds of light to finally darken the whole of Olympus (223). Unlike Nietzsche who believed that tragedy was a balance of the Dionysian and the Apollonian, Hauptmann here stresses its chthonic origins.

Hauptmann's journey to Greece, which he likens to a pilgrimage, exerted a deep and lasting impact on him. Throughout his travel diary he expresses happiness and excitement about his experiences and his love for the country in which he felt rejuvenated. The diary vividly conveys not only the beauty of the landscape, but also Hauptmann's impressions of ancient Greece. In it he contributes to discourses on Hellenism by stressing, for example, the chthonic powers of tragedy that he sensed strongly in Delphi, as well as the joyousness and vitality he perceived. Throughout his stay he felt that Greece was his spiritual home.

\section{Bibliography}

Butler, E. M. (1935). The Tyranny of Greece over Germany: A Study of the Influence Exercised by Greek Art and Poetry Over the Great German Writers of the Eighteenth, Nineteenth and Twentieth Centuries. London: Cambridge University Press.

Garten, H. F. (1954). Gerhart Hauptmann. New Haven: Yale University Press.

Guthke, K. S. (1961). Gerhart Hauptmann: Weltbild im Werk. Göttingen: Vandenhoek \& Ruprecht.

Hauptmann, G. (1948). Agamemnons Tod. Berlin: Suhrkamp.

Hauptmann, G. (1914). Der Bogen des Odysseus. Berlin: Fischer.

Hauptmann, G. (1948). Elektra. Berlin: Suhrkamp.

Hauptmann, G. (1908). Griechischer Frühling. Berlin: Fischer.

Hauptmann, G. (1944). Iphigenie in Aulis. Berlin: Suhrkamp.

Hauptmann, G. (1941). Iphigenie in Delphi. Berlin: Fischer.

Maurer, W. R. (1992). Understanding Gerhart Hauptmann. Columbia S. C.: University of South Carolina Press.

Meid, C. (2012). Griechenland-Imaginationen: Reiseberichte im 20. Jahrhundert von Gerhart Hauptmann bis Wolfgang Koeppen. Berlin: De Gruyter.

Nietzsche, F. (1956). The Birth of Tragedy and The Genealogy of Morals. Trans. F. Golffing. Garden City, New York: Doubleday.

Oldfather, W. A. (1910). 'Hauptmann's Griechischer Frühling.' The Classical Journal 6 (1): 15-23. 
Petrovic-Wriedt, A. (2010). Zwischen Tradition und Zeitbezug - Gerhart Hauptmanns Atriden-Tetralogie. Munich: Grin Verlag.

Said, E. W. (1978). Orientalism. New York: Pantheon.

Santini, D. (1998). Gerhart Hauptmann zwischen Modernität und Tradition: Neue Perspektiven zur Atriden-Tetralogie. Berlin: Erich Schmidt.

Thompson, C. (2011). Travel Writing. London and New York: Routledge.

Uysal, M. (2009). 'Einst war Gerhart Hauptmann in Istanbul: Ein Beitrag zur Untersuchung der deutschen Reiseberichte über die Türkei.' Journal of Social Science 20: 253-264. Available at http://sablon.sdu.edu.tr/dergi/sosbilder/en/? Sayfa=arsiv\&bilgi=sayi-20 [20 February 2013].

Winckelmann, J. J. (1764). Geschichte der Kunst des Alterthums. Dresden: In der Waltherischen Hof-Buchhandlung.

Winckelmann, J. J. (1850). The History of Ancient Art Among the Greeks. Trans. G. H. Lodge. London: J. Chapman. 